\title{
An Overview of Design Considerations for Small Recirculating Fish Culture Systems
}

\author{
T.S. Harmon \\ Walt Disney World Co. \\ P.O. Box 10,000 \\ Lake Buena Vista, FL 32830 USA
}

\section{ABSTRACT}

Aquatic system engineering is an important factor when designing a new fish holding system or renovating an existing system. Indoor recirculating aquatic systems may be used for various operations, some of which may include: the quarantine of new animals, isolation for ill fish, aquaculture, research, or as educational displays. Professional engineers generally design large or high-density systems using a massbalance approach. However, smaller systems are typically designed or renovated by their immediate owners, which may include aquaculturalists, aquarists, biologists, zoologists, or professors. In many instances trial and error is used to size the equipment, which can get very expensive and take up valuable time. Undersized or oversized equipment wastes electricity and possibly reduces the life of the equipment. These limitations can be avoided by using the practical guidelines given here and taking into consideration a few simple design factors. Proper design of these systems can be accomplished by much quicker methods than a full-scale mass-balance approach and will typically work for low-density systems. 


\section{INTRODUCTION}

Recirculating systems offer two distinct advantages; the control over certain water quality parameters, and water conservation. Most water reconditioning systems recycle $90-95 \%$ of the water (Piper et al. 1982). A daily water loss may be necessary due to backwashing of filters as well as for the removal of nitrates (Lawson 1995). Universities and high schools often use recirculating aquatic systems for studying aquatic animals and their behaviors, while other universities may use them for aquacultural research. Public aquariums and zoological institutions that have aquatic exhibits may also have holding facilities to receive and quarantine new animals as well as to care for ill animals. All recirculating aquatic systems should be designed according to their intended use. Moreover, a facility or system is often tumed into another with a different use later on. Reusing existing equipment can be very cost-effective, but we must consider the required components and the limitations of the original design before placing a load of fish into an existing system and expecting good results.

Facility or system design depends directly upon the desired use of a system. Typical uses may include: display exhibits, quarantine, hospital tanks, holding, breeding, growout, spawning or any combination of these. Even after the original application is decided the actual components needed may depend upon another set of factors. These factors may include: water availability and cost, feeding rates, fish density, electrical availability, maintenance, and climate. Small or large recirculating systems alike require five basic components to run properly; a tank of adequate shape and size, good aeration, pumps, mechanical filters, and biological filters. Design of each of these components is crucial, as they are essential for the system's overall performance.

\section{HOLDING CONTAINERS}

There are many different types, shapes, and sizes of holding tanks available today, with the most popular being circular or rectangular. Much of the selection with tank shape is based on personal preferences, although some have distinct advantages over others. A major contrast outlined by Piedrahita (1991) is that the water quality in circular tanks

International Journal of Recirculating Aquaculture, volume 2 
tends to be uniform, while rectangular raceways are characterized by a distinct degradation of water quality between the inlet and outlet.

Rectangular tanks can be placed side by side with little wasted space between them. Ellis (1994) found rectangular tanks to be superior over circular designs in survivability, feed conversion, yield, and growth of Florida red tilapia fry. If flow rates are not adjusted correctly in raceways, they can act as a solids settling device. Boersen and Westers (1986) and Kindschi et al. (1991) found that adding baffles to raceways prevented solids from settling out within the raceway, making for easy removal at the end of the raceway. Dividers can also be easily constructed and placed into narrow rectangular tanks compared to circular tanks.

Circular tanks offer the distinct advantage of being "self-cleaning". Incoming water can be angled to create a circular motion in the tank with the solids being swept towards the middle where they are removed by a center drain. Lawson (1995) reminds us that flow velocity must not be so great that the fish expend all of their energy swimming. Moreover, tanks with high water velocities may keep particulate matter suspended and create conditions in which gill irritation develops (Wedemeyer 1996). The ideal flow velocity for fish will vary between species and even within a species depending on the condition and size of fish.

\section{AERATION}

Dissolved oxygen (DO) is a limiting factor in fish culture (Piper et al. 1982). Inadequate DO levels may lead to reduced growth, an increase in disease, and can cause mass mortality (Colt and Tchobanoglous 1981). As the stocking density and food intake increases in a system, so must the amount of available oxygen. Species, life stage,size, and physiological condition of the fish, as well as overall environmental conditions are all variables which can affect the amount of oxygen consumed by the system. In most cases, long-term DO levels above 6.0 $\mathrm{mg} / \mathrm{will}$ prevent any problems associated with oxygen deficiency in any species of fish. Warm water fish generally tend to tolerate lower DO levels for longer periods, whereas cool or cold water fish tend to require higher levels over the long term. 
Subsurface aeration techniques are the most common among lightly loaded fish holding systems. In facilities that are planning for high densities of fish, pure oxygen injection may be preferred. Speece (1981) and Colt and Watten (1988) describe different types of pure oxygen systems and their uses.

For low densities of fish, using professional judgment from previous personal experience or from the experience of colleagues can be a great help and save time with calculations in determining the correct size of the aeration device. If previous experience is limited, it is recommended that the actual amount of oxygen consumed by the fish be taken into consideration (Table 1). Even among the same species, oxygen uptake can be inconsistent because of the many variables that are involved with the rate of oxygen consumption. Rusch (2000) described a quick approach to oxygen consumption design suitable for small or lightly loaded systems, where fish use $220 \mathrm{~g} \mathrm{O} / \mathrm{kg}$ of feed and bacteria in the system consume about $75 \%$ of the fish consumption rate $(165 \mathrm{~g} \mathrm{O} / \mathrm{kg}$ feed). A mass-balance approach described by Losordo (1991) is typically used to design high-density aquaculture systems.

Considerations such as the DO level entering the tank and turnover rates are also important in designing an aeration system. Assuming an incoming DO level of $0 \mathrm{mg} /$ can provide a safety margin by not relying on the system's passive aeration to maintain proper DO levels.

Air blowers or air compressors are usually the choice for subsurface aeration devices. Air blowers are designed to provide large volumes of air at low pressures $\left(<4 \mathrm{lb} / \mathrm{in}^{2}(\mathrm{psi}), 1 \mathrm{Bar}=14.5 \mathrm{psi}\right)$ with the opposite holding true for air compressors. Correct sizing is critical for both blowers and compressors. Oversizing can generate excess amounts of air and may need to be "blown off". One that is too small may not fully supply all the airstones, or operate only at shallow depths. The total amount of pressure and volume of air is required knowledge for sizing an aeration device, and is dependent upon three variables:

(1) The depth of water at which the airstone(s) will be operated: Ipsi $=0.7 \mathrm{~m}$ of water at $15.6^{\circ} \mathrm{C}$.

(2) Different size diffusers and pore size will determine the amount of air needed to operate them: The volume needed is usually 
given in liters per minute or cubic feet per minute (CFM), (1 $\mathrm{CFM}=28.3 \mathrm{~L} / \mathrm{min}$ ). This can be obtained from the manufacturer of the diffuser; most airstones used for small systems are well under $28 \mathrm{~L} / \mathrm{min}$. A total volume from all diffusers used is required for a total volume of air.

(3) Friction losses in the pipe: Creswell (1993) compiled information on frictional losses (psi loss/30.5 m pipe) for air as a function of pipe size and flow rate.

Once the volume of air required, amount of pressure (psi) required, and type of aeration device preferred is known, a simple graph provided by the supplier will give the proper size compressor or blower that is needed for the job.

Table 1. Oxygen consumption values for various freshwater fish species.

\begin{tabular}{|c|c|c|c|c|}
\hline Species & $\begin{array}{l}\text { Size } \\
\text { (g) }\end{array}$ & $\begin{array}{l}\text { Temp } \\
\left({ }^{\circ} \mathrm{C}\right)\end{array}$ & $\begin{array}{l}O_{2} \text { consumption } \\
(\mathrm{mg} / \mathrm{kg} / \mathrm{day})\end{array}$ & Original Source \\
\hline $\begin{array}{l}\text { Cyprinus } \\
\text { carpio }\end{array}$ & $\begin{array}{l}806 \\
100 \\
100 \\
100\end{array}$ & $\begin{array}{l}12 \\
10 \\
20 \\
25\end{array}$ & $\begin{array}{r}1,921 \\
4,080 \\
11,520 \\
16,800\end{array}$ & $\begin{array}{l}\text { Nakanishi \& Itzawa 1974(1) } \\
\text { Beamish 1964(2) } \\
\text { Beamish 1964(2) } \\
\text { Beamish 1964(2) }\end{array}$ \\
\hline $\begin{array}{l}\text { Oncorhynchus } \\
\text { nerka }\end{array}$ & $\begin{array}{l}28.6 \\
28.6\end{array}$ & $\begin{array}{l}15 \\
15\end{array}$ & $\begin{array}{l}6,600 \\
5,600\end{array}$ & $\begin{array}{l}\text { Brett \& Zala } 1975^{(3)} \\
\text { Brett \& Zala } 1975^{(3)}\end{array}$ \\
\hline $\begin{array}{l}\text { Ictalurus } \\
\text { punctatus }\end{array}$ & $\begin{array}{l}100 \\
100 \\
100\end{array}$ & $\begin{array}{l}26 \\
30 \\
30\end{array}$ & $\begin{array}{l}14,600 \\
13,440 \\
19,440\end{array}$ & $\begin{array}{l}\text { Andrews \& Matsuda } 1975^{(1)} \\
\text { Andrews \& Matsuda } 1975^{(2)} \\
\text { Andrews \& Matsuda } 1975^{(2)}\end{array}$ \\
\hline $\begin{array}{l}\text { Oncorhynchus } \\
\text { mykiss }\end{array}$ & $\begin{array}{l}73 \\
100\end{array}$ & $\begin{array}{l}11 \\
15\end{array}$ & $\begin{array}{l}2,917 \\
7,200\end{array}$ & $\begin{array}{l}\text { Nakanishi \& Itazawa 1974(1) } \\
\text { Liao } 1971^{(2)}\end{array}$ \\
\hline \multicolumn{2}{|c|}{ Sources taken from: } & $\begin{array}{l}\text { (1) } \\
(2) \\
(3)\end{array}$ & $\begin{array}{l}\text { Kepenyes and Var } \\
\text { Creswell (1993) } \\
\text { Colt and Tchoban }\end{array}$ & $\begin{array}{l}\text { radi (1983) } \\
\text { oglous (1981) }\end{array}$ \\
\hline
\end{tabular}




\section{PUMPS}

Recirculation systems generally utilize pumps for moving water from the tank through filters or from a sump through a filtering system. Although multiple factors play into the required flow rates, a tank exchange of at least once an hour is usually sufficient to maintain the water quality needed for proper fish health. If a heavy feeding regime or excellent clarity is necessary, a quicker turnover rate should be considered. Wheaton et al. (1997) uses oxygen consumption as a factor in the determination of flow rate. Losordo and Westers (1997) review the mass-balance approach, where the desired flow rate is computed by taking variables such as dissolved oxygen and ammonia concentrations into consideration.

Four items of information are needed to correctly size a pump:

(1) Desired flow rate

(2) Friction loss from the piping and fittings (suction \& discharge side)

(3) Vertical distance over which the water is to be pumped

(4) Pressure required by filters

Creswell (1993) and Lawson (1997) gathered information on friction losses for selected valves and fittings as "equivalent length of pipe". Using this information, the total length of all fittings is added to the length of straight pipe needed to give a total length of pipe, which is then used in the Hazen-Williams formula. Major pipe sizes and their corresponding friction losses are shown in Table 2. Lawson (1997) recommends using a $\mathrm{C}$-value (Hazen-Williams coefficient for various pipe materials) of 100 for permanent installations of $\mathrm{PVC}$ piping due to future biofouling; new PVC pipe has a C-value of 150 . This calculation along with vertical lift and pressures required by any filters will give the total dynamic head. This information along with the desired flow rate will determine which size pump is best suited for the application.

10 International Journal of Recirculating Aquaculture, volume 2 


\section{Table 2}

Losses are given in head feet per $30.5 \mathrm{~m}\left(100^{\prime}\right)$ of pipe using the Hazen-Williams formula. A C-value of 130 is used as the coefficient using Schd. 40 PVC pipe. Velocity (v) is given in $\mathrm{fv} / \mathrm{sec}(1 \mathrm{ft} / \mathrm{sec}=18.29 \mathrm{~m}$ min). Divide the loss (head feet) by 3.28 to obtain meters of head. LPM is liters per minute, and GPM is gallons per minute.

Pipe Size mm (in)

\begin{tabular}{|c|c|c|c|c|c|c|c|c|c|}
\hline & & 1910. & 75) & 250 & & 38 & (1.5) & & (2) \\
\hline LPM & GPM & Loss Ve & elocity. & Loss $V$ & elocity & Loss & Velocity & Loss & Velocity \\
\hline 19 & (5) & 10.17 & 3.63 & & & & & & \\
\hline 39 & (10) & 36.73 & 7.26 & 9.05 & 4.09 & 1.26 & 1.82 & 0.31 & 1.02 \\
\hline 78 & (20) & 132.58 & 14.52 & 32.67 & 8.17 & 4.53 & 3.63 & 1.12 & 2.04 \\
\hline 116 & (30) & & & 69.21 & 12.26 & 9.61 & 5.45 & 2.37 & 3.06 \\
\hline 155 & (40) & & & 117.9 & 16.34 & 16.37 & 7.26 & 4.03 & 4.09 \\
\hline 194 & (50) & & & 178.24 & 20.43 & 24.75 & 9.08 & 6.10 & .5 .11 \\
\hline 233 & (60) & & & & & & 10.89 & 8.54 & 6.13 \\
\hline 271 & (70) & & & & & & & 10.99 & 7.15 \\
\hline 310 & (80) & & & & & & & 13.43 & 8.17 \\
\hline 349 & (90) & & & & & & & 15.89 & 9.19 \\
\hline 388 & (100) & & & & & & & 18.37 & 10.21 \\
\hline
\end{tabular}

Note: Crane (1988) notes that for general service applications a reasonable velocity is not to exceed $3.0 \mathrm{~m} / \mathrm{sec}(10 \mathrm{ft} / \mathrm{sec})$. 


\section{FILTRATION}

Recirculation systems rely upon filtration to remove waste products and to carry out the nitrification processes. Basic components of a recirculation system often include: mechanical filtration, biological filtration, sterilization, and heating/cooling. Various tertiary components such as fractionators and carbon filters may also be added to a system.

Mechanical filters are typically the first filters in a filtration sequence. Manufacturers will rate mechanical filters according to a flow rate and are sized accordingly. A good review of mechanical filters is found in Wheaton (1977), Chen et al. (1997), and Lawson (1997). The biological filtration of interest for fisheries professionals is the nitrification process in which several genera of autotrophic bacteria convert ammonium $\left(\mathrm{NH}_{4}^{+}\right)$to nitrite $\left(\mathrm{NO}_{2}^{-}\right)$then to nitrate $\left(\mathrm{NO}_{3}{ }^{-}\right)$(Wheaton 1977). Biofilters provide a large surface area for nitrifying bacteria to colonize, which the water has to pass over or through. A biological filtering device should be located following the mechanical filter. Reliable reviews of biological filtration devices used in fish systems include: Wheaton (1977); Rogers (1985); Malone et al. (1993); Westerman et al. (1993); and Wheaton et al. (1997).

Biological filtration design is not an exact science in fish systems due to limited scientific literature on ammonia production by fish and inconsistencies in the data that do exist (Wheaton 1997). Malone et al. (1993) also expresses that 30-60\% of nitrification can take place outside of the biofilter: Biological filters are sized according to the amount of surface area that is needed for nitrifying bacteria. Meade (1985) reviewed information on fish ammonia production and found ranges of 20-78.5 g/kg - diet/day. Three out of the five sources cited by Meade found production rates between 31-37.4 g/kg-diet/day. Piper (1982) found that much of the literature on trout and salmon total ammonia production rates, which were fed a dry-pelleted food, produced $32 \mathrm{~g} / \mathrm{kg}$ food. For smaller, lightly loaded systems, submerged or trickling biofilters are commonly used and are relatively inexpensive. Wheaton (1977) reviewed literature on nitrification rates for a submerged gravel biofilter to be $1.0 \mathrm{~g} / \mathrm{NH}_{3}-\mathrm{N} / \mathrm{m}^{2}$-day at $20^{\circ} \mathrm{C}$. Miller and Libey (1985) found a trickling filter to have removal rates from $0.14-0.25 \mathrm{~g} \mathrm{~N} / \mathrm{m}^{2}$-day. Bead filters were found to have removal rates of $0.27 \mathrm{~g} \mathrm{TAN} / \mathrm{m}^{2} /$ day

12 International Journal of Recirculating Aquaculture, volume 2 
(Lawson 1995). Using these findings, the following formula is used to determine the surface area needed.

$\frac{\text { ammonia produced }(g)}{\text { ammonia removal }\left(\mathrm{g} / \mathrm{m}^{2} / \text { day }\right)}=\mathrm{m}^{2}$ surface area

Poor performance of biofilters is most often caused by uneven flow across all of the media (Hochheimer and Wheaton 1991). The nitrifying bacteria must have an ample supply of nutrients and an adequate supply of oxygen to survive. Hochheimer and Wheaton (1991) review various physical and chemical factors that may inhibit nitrifying bacteria growth. Losordo (1991) and Lawson (1995) describe a mass-balance approach to biological filter design that is commonly used for the design of highdensity systems.

\section{CALCULATIONS}

The following example is for a recirculating system used as a holding area for freshwater fishes. The following information is used in the design process:
A. School aquaculture system for warm water fish.
Total weight of fish not to exceed $50 \mathrm{~kg}$.
B. Total feed is not to exceed $2 \mathrm{~kg} /$ day.
C. $2835 \mathrm{~L}(750 \mathrm{gal})$ system; 2- $945 \mathrm{~L}$ circular tanks and 1- $945 \mathrm{~L}$ rectangular trough.
D. Components consist of a sand filter, trickling biofilter, UV sterilizer, and supplemental aeration.

1. FLOW RATE: Turnover rate $1 \times / \mathrm{hr}$. $(2835 \mathrm{~L} / 60 \mathrm{~min}=47.25 \mathrm{~L} / \mathrm{min}(13 \mathrm{gpm})$

One inch Schd. 40 PVC pipe will be used, which will have a velocity of about $91.5 \mathrm{~m} / \mathrm{min}(3 \mathrm{ft} / \mathrm{sec}$ ) and a head loss of around 4.5 meters ( 15 feet) head/30.5 m pipe (Table 2 ). 
2. PLUMBING FITTINGS: From Creswell (1993), the following losses are given in equivalent length of pipe:

\begin{tabular}{l|l|l|c|l|l}
\hline \multicolumn{2}{l|}{ DISCHARGE (Outflow) } & \multicolumn{3}{l}{ SUCTION (Inflow) } \\
\hline Qty. & Part & Equiv. Pipe & Qty. & Part & Equiv. Pipe \\
\hline 8 & $90^{\circ}$ elbows & 6.4 m pipe & 2 & $90^{\circ}$ elbows & 1.5 m pipe \\
4 & $45^{\circ}$ elbows & 1.7 & & Straight pipe & 0.9 \\
2 & $\begin{array}{l}\text { Tees } \\
\text { (branch flow) }\end{array}$ & 3.2 & & TOTAL SUCTION & 2.4 m pipe \\
\cline { 3 - 5 } 6 & $\begin{array}{l}\text { Gate Valves } \\
\text { (open) }\end{array}$ & 2.1 & & & \\
& Straight pipe & 3.0 & & & \\
\end{tabular}

\section{TOTAL DISCHARGE $16.4 \mathrm{~m}$ pipe}

3. FILTRATION COMPONENTS: Vertical distance from sump water to the highest point; where the water is discharged into the trickling filter $=\mathbf{2} \mathbf{~ m}$

Sand filter $=3$ psi $=2.1$ meters head $\mathrm{UV}=$ minimal (from manufacturer)

4. TDH (total dynamic head): $T D H=$ friction head + pressure head + static head + velocity head (minimal)

$18.8 \mathrm{~m}$ pipe (suction + discharge)

Head loss $4.5 \mathrm{~m} / 30.5 \mathrm{~m}$ pipe (from \#1,Table 2.0 ) $(18.8 \mathrm{~m})(4.5 \mathrm{~m} / 30.5 \mathrm{~m})=2.8 \mathrm{~m}$

velocity head $=$ velocity ${ }^{2} / 2 g=V^{2} / 2(32.2)=($ minimal $)$ $\mathrm{g}=$ gravitational constant

$$
\text { TDH }=2.8+2.1+2=6.9 \text { meters head }
$$

Therefore, a pump that would supply $47 \mathrm{~L} / \mathrm{min}$ (13 gpm) at 7 meters of head is needed. It is recommended that a pump that is slightly larger be used to take into consideration any plumbing modifications that may be considered later. 
5. AERATION REQUIREMENTS: From Table 1 we find $14,600 \mathrm{mg} / \mathrm{kg} /$ day $\mathrm{O}_{2}$ consumption for catfish at $26^{\circ} \mathrm{C}$.

$(50 \mathrm{~kg}$ fish $)(14,600 \mathrm{mg} / \mathrm{kg} /$ day $)=730,000 \mathrm{mg} /$ day $\mathrm{O}_{2}$ consumption

According to a supplier, a $15 \mathrm{~cm}$ (6") airstone has an output of $8 \mathrm{~g} \mathrm{O}_{2} / \mathrm{hr}(192,000 \mathrm{mg} \mathrm{O} /$ day $)$.

$730,000 \mathrm{mg} /$ day $\mathrm{O}_{2}$ consumption

$192,000 \mathrm{mg} \mathrm{O} /$ day output each

=(4) $15 \mathrm{~cm}$ airstones

Note: Because we are using a trickling filter, which will also oxygenate the water, oxygen consumed by bacteria is not included. Also, water entering the tank is assumed to have a DO level of $0 \mathrm{mg}$.

6. AERATION DEVICE: $15 \mathrm{~cm}$ airstones are suggested to run at $14 \mathrm{~L} / \mathrm{min}$ (supplied from manufacturer) each.

$14 \mathrm{~L} / \min (4)=56 \mathrm{~L} / \mathrm{min}$

Friction loss due to flow and pipe size is minimal for this volume of air (Creswell 1993). With a depth of $0.7 \mathrm{~m}$, about $1 \mathrm{psi}$ of pressure is required. This minimal air volume will require a small air pump capable of $60 \mathrm{~L} / \mathrm{min} @ 1.5-2$ psi. and using these figures there is a buffer.

7. BIOLOGICAL: Feeding at a rate of $2 \mathrm{~kg} /$ day and using a production rate of $35 \mathrm{~g} \mathrm{~N} / \mathrm{kg}$ feed $=70 \mathrm{~g} \mathrm{~N}$ produced/day

Using a removal rate of $0.14 \mathrm{~g} / \mathrm{m}^{2} /$ day for a trickling filter

$$
\frac{70 \mathrm{~g} \mathrm{~N}}{0.14 \mathrm{~g} / \mathrm{m}^{2} / \text { day }}=500 \mathrm{~m}^{2} \text { surface area }
$$

$2.54 \mathrm{~cm}$ bioballs $=532 \mathrm{~m}^{2}$ surface area $/ \mathrm{m}^{3}$ (given by supplier)

Therefore, one cubic meter of bioballs is needed for the trickling filter.

International Journal of Recirculating Aquaculture, volume $2 \quad 15$ 


\section{CONCLUSIONS}

The considerations mentioned are only a few of many needed for the design of an aquatic holding system. However, this paper will give the non-engineer a starting point in the design phase and eliminate some of the guessing that is often involved in system design. Proper design of any system is the basis for its performance. Without proper design, water quality will likely limit the systems capability to properly house healthy fish over a period of time. Moreover, by being involved in the design phase of a system, the owner will better understand the limits of the system. 


\section{REFERENCES}

Boersen, G., Westers, H. Waste Solids Control in Hatchery Raceways. The Progressive Fish Culturalist 1986. 48, 151-154.

Chen, S., Stechey, D., Malone, R.F. Suspended Solids Control in Recirculating Aquaculture Systems. In Aquaculture Water Reuse

Systems: Engineering Design and Management; Timmons, M.B. and Losordo, T.M., Eds. 1997. Elsevier: New York, NY, USA.

Colt, J.E., Tchobanoglous, G. Design of Aeration Systems for Aquaculture. In Proceedings of the Bio-engineering Symposium for Fish Culture; Allen, L.J. and Kinney, E.C., Eds. 1981. American Fisheries Society, Bethesda, MD, USA.

Colt, J., Watten, B. Applications of Pure Oxygen in Fish Culture. Aquacultural Engineering 1988. 7, 397-441.

Crane Co. 1988. Flow of Fluids Through Valves, Fittings, and Pipe. Crane Co., Joliet, IL, USA.

Creswell, R.L. 1993. Aquaculture Desk Reference. Chapman and Hall: New York, NY, USA.

Ellis, S.C., Watanabe, W. Comparison of Raceway and Cylindroconical Tanks for Brackish-Water Production of Juvenile Florida Red Tilapia Under High Stocking Densities. Aquacultural Engineering 1994. 13, 59-69.

Hochheimer, J.N., Wheaton, F.W. Understanding Biofilters, Practical Microbiology for Ammonia Removal. In Engineering Aspects of Intensive Aquaculture: Proceedings from the Aquaculture Symposium. NRAES-49; 1991. Northeast Regional Agricultural Engineering Service, Ithaca, NY, USA.

Kepenyes, J., Varadi, L. Aeration and Oxygenation. In Inland Aquaculture Engineering. ADCP/REP/84/21; Pillay, T.V. R., Clay, C.H., Kovart, J., Eds. 1984. Food and Agriculture Organization of the United Nations, Rome, Italy. 
Kindschi, G.A., Thompson, R.G., Mendoza, A.P. Use of Raceway Baffles in Rainbow Trout Culture. The Progressive Fish Culturalist 1991. 53, 97-101.

Lawson, T.B. 1995. Fundamentals of Aquacultural Engineering.

Chapman and Hall: New York, NY, USA.

Losordo, T.B. An Introduction to Recirculating Production System

Design. In Engineering Aspects of Intensive Aquaculture:

Proceedings from the Aquaculture Symposium. NRAES-49; 1991.

Northeast Regional Agricultural Engineering Service, Ithaca, NY, USA

Losordo, T.M.,Westers, H. System Carrying Capacity and Flow

Estimation. In Aquaculture Water Reuse Systems: Engineering

Design and Management: Timmons, M.B., and Losordo, T.M., Eds. 1997. Elsevier: New York, NY, USA.

Malone, R.F., Chitta, B.S., Drennan, D.G. Optimizing Nitrification in Bead Filters for Warmwater Recirculating Aquaculture Systems. In: Techniques for Modern Aquaculture (Proc.); Wang, J.K., Ed. 1993. American Society of Agricultural Engineers, St. Joseph, MI, USA.

Meade, J.W. Allowable Ammonia for Fish Culture. The Progressive Fish Culturalist 1985. 47(2), 135-145.

Miller, G.E., Libey, G.S. Evaluation of Three Biological Filters Suitable for Aquacultural Applications. Journal of World Mariculture Society 1985. 16,158-168.

Piedrahita, R.H. Engineering Aspects of Warmwater Hatchery Design.

In Aquaculture Systems Engineering (Proc.); ASAE 02-91, Giovannini, P., Ed. 1991. American Society of Agricultural Engineers, St. Joseph, MI, USA.

Piper, R.G., McElwain, I.B., Orme, L.E., McCraren, J.P., Fowler, L.G., Leonard, J.R. 1982. Fish Hatchery Management. U.S. Department of the Interior, Fish and Wildlife Service, Washington, DC, USA.

Rogers, G.L., Klemetson, S.L. Ammonia Removal in Selected Aquaculture Water Reuse Biofilters. Aquacultural Engineering 1985. 4,135-154.

18 International Journal of Recirculating Aquaculture, volume 2 
Rusch, K. Basic Water Quality Principles. In Recirculating System

Fundamentals, Special Session Proceedings from the World

Aquaculture Society Annual Conference, 2000. Aquacultural Engineering Society.

Speece, R.E. Management for Dissolved Oxygen and Nitrogen in Fish

Hatchery Waters. In Proceedings of the Bio-Engineering Symposium

for Fish Culture. Allen, L.J. and Kinney, E.C., Eds. 1981. American Fisheries Society, Bethesda, MD, USA.

Wedemeyer, G.A. 1996. Physiology of Fish in Intensive Culture

Systems. Chapman and Hall: New York, NY, USA.

Westerman, P.W., Losordo, T.M., Wildhaber, M.L. Evaluation of

Various Biofilters in an Intensive Recirculating Fish Production

Facility. In Techniques for Modern Aquaculture (Proc.). Wang, J.K.,

Ed. 1993. American Society of Agricultural Engineers, St. Joseph, MI, USA.

Wheaton, F.W. 1977. Aquacultural Engineering. John Wiley and Sons:

New York, NY, USA.

Wheaton, F.W., Hochheimer, J., Kaiser, G.E., Malone, R.F., Krones, M.J., Libey, G.S., Easter, C.C. Nitrification Filter Design Methods in Aquaculture Water Reuse Systems: Engineering Design and Management. In Aquaculture Water Reuse Systems:Engineering Design and Management. Timmons, M.B., and Losordo, T.M. Eds. 1997. Elsevier: New York, NY, USA. 